\title{
Comparative analysis of selected freight means in the aspect of EMS sets implementation
}

\author{
Anna Dzioba ${ }^{1 *}$, Eukasz Muślewski², Jan Gutsche $^{2}$, Dragutin Lisjak ${ }^{3}$ and Michał Sójka ${ }^{1}$ \\ ${ }^{1}$ Cuiavian University in Wloclawek, the Faculty of Social and Technical Sciences, Okrzei 94A, 87- \\ 800 Włocławek, Poland \\ ${ }^{2}$ UTP University of Science and Technology, the Faculty of Mechanical Engineering, Al. prof. S. \\ Kaliskiego 7, 85-796 Bydgoszcz, Poland \\ ${ }^{3}$ University of Zagreb, Faculty of Mechanical Engineering and Naval Architecture, Ivana Luciuca \\ Street 5, 10002 Zagreb, Croatia
}

\begin{abstract}
The Three Seas Initiative, which gathers 12 European countries located from the Baltic Sea, the Adriatic Sea to the Black Sea, is both an opportunity and a challenge for the countries of Central and Eastern Europe. The concept has primarily a regional dimension, while its global impact is appreciated and supported by, among others, Scandinavian countries and the U.S. government. While the potential for economic development within the scope this initiative is high, in order to develop it, there is a need to modernize the transporting, energetic and digital infrastructure necessary for the implementation of logistic processes. It is also necessary to change legal regulations. The article describes the international economic and political initiative gathering selected countries in the Three Seas area and characterizes the purposefulness of the application of European Modular Systems. On the basis of previously selected features influencing the increase of economic efficiency and appropriately selected weights, a comparative analysis of selected cargo means was conducted. The Bellinger's method was applied in order to conduct the comparative analysis. Based on the analysis of the obtained research results, the benefits of using sets with increased loading capacity on a selected route between the ports of the Baltic Sea and the Adriatic Sea were demonstrated.
\end{abstract}

\section{Introduction}

The demand for the provision of transportation services is growing steadily. The most popular and the most used transport branch is road transport, at the same time aiming at the development of intermodal transport. The globalization process is expanding year by year. Countries all over the world are striving for integration, opening borders, which has a positive effect on trade. International transport is currently in the phase of dynamic development, and the exchange of goods is an indispensable element of this globalization [1].

*Corresponding author: annadzioba1@gmail.com 
Countries interact with each other, undertaking cooperation in the development of transport, energy and digital infrastructure, which is necessary for the proper implementation of logistic processes. An example of such cooperation is the Three Seas Fund, described in this article, concluded between European countries located in the region of the Three Seas, which foresees the implementation of infrastructure projects [2].

Another factor influencing the globalization process is aiming at reducing transportation costs, shortening service provision time, and increasing cargo space. [1].

The study characterizes the European Modular Systems with an indication of the purposefulness of implementing road trains in road transport of goods in Europe. The study aims to conduct a comparative analysis using the Bellinger's method, in which the benefits of using vehicle sets of greater loading capacity between the Baltic Sea and Adriatic Sea ports are demonstrated.

\section{International Economic and Political Initiative of the Three Sea}

The international economic and political initiative of the Three Seas was established as a project in 2015. The aim of the initiative is to improve the cooperation between 12 countries located in the region of the Black Sea (to the southeast), the Baltic Sea (to the north) and the Adriatic Sea (to the southwest) [2, 3]. On 25 - 26 August 2016 in Dubrovnik, where the leaders of the six countries met, the Three Seas Initiative was brought to life i.e. a joint declaration was signed, which gave birth to the Three Seas Initiative. The initiators of the meeting were the Presidents of Croatia and Poland, what is more the Presidents of Hungary, Lithuania, Slovenia, Bulgaria, the Minister of Transport of the Czech Republic and Romania, the Deputy Prime Minister for Investment and Information Technology of Slovakia, the Deputy Foreign Affairs Minister of Austria, the Undersecretary of State of the Ministry of Foreign Affairs of Estonia and the Director of the Transit Policy Department of Latvia participated in the summit $[3,4]$. The Three Seas region includes the countries identified in the Joint Declaration on the Three Seas Initiative, otherwise known as the Dubrovnik Declaration, and they are: Poland, Austria, Bulgaria, Croatia, Estonia, Lithuania, the Czech Republic, Hungary, Romania, Slovenia, Slovakia and Latvia. In accordance with the aforementioned declaration, the cooperation under the agreement is to include the implementation of strategic activities in the area of logistics and transport, energy, as well as IT and communications in the Central and Eastern Europe [4,5]. The above-mentioned activities are very important from the point of view of social and economic development of the aforementioned countries, which is emphasized by the presidents of the countries. The purpose of the Fund is to lead to the generation of financial resources to finance infrastructure projects [6].

Among the projects being implemented within the framework of the Three Seas are: Via Carpatia and Via Baltica [4].

The aim of the Via Carpatia project is to create an international transport route running from Lithuania through Poland, Slovakia, Hungary, Romania, Bulgaria up to Greece. The implementation of the project is an opportunity for the development of Central and Eastern European countries. This will contribute to increasing and improving the quality of infrastructure, which will make it possible to reduce communication barriers blocking the proper execution of logistic processes in this part of Europe [4,7]. It is assumed that on the Via Carpatia route, $760 \mathrm{~km}$ of expressway are to be put into service by 2025 . Ultimately, the Eastern European route will be about 3 thousand km long [8].

The second of the ongoing projects is the Via Baltica project, which is a transport route connecting the Baltic countries with Western Europe [9]. The above investments in transport infrastructure are important for the safety and development of Northeast Poland. Via Baltica is the popular name for the international road E67, which serves as the most important road 
connection between the Baltic States and Poland. The investment in the extension of the S61 Via Baltica will allow for social and economic boost to some regions of Poland, contribute to the efficient movement of cargo and people, which is very important in view of the increasing demand for the execution of transport services [10], and improve transport connections with Scandinavia, where the modular systems studied in this paper have already been in operation for many years.

In addition to the above-mentioned projects, within the scope of the Three Seas Initiative projects related to the improvement of energetic and digital infrastructure will be implemented, which is necessary for the proper execution of logistic processes. The Tricity Fund is a very large undertaking whose task is to involve investors in infrastructure projects. The initiator of the program is Bank of National Farm. Funds for the investment are to come from European, national and local government funds and from private investors [11].

\section{Characteristics of European Modular Systems}

European Modular Systems (EMS) have been in use around the world since the 1930s, so the date can be considered as the beginning of functioning of this type of vehicle. Australia was a pioneer who initiated the use of EMS in its territory. In this country, long vehicles travelled between cities, over long distances $[12,14]$. Besides the abovementioned country, long trucks are also used in the world in: the United States, Canada, Mexico and Argentina [12,13]. Transporting with the use of longer and heavier vehicles is also carried out in Europe. As a result of the analysis of source materials on the continent the vehicles are used in 10 countries of the European Union. The first European country that allowed the general use of longer vehicles in its territory was Sweden, followed by the Netherlands, Denmark, Finland, Germany, Norway and Spain, Portugal, the Czech Republic and Belgium. Most of these countries allow driving long vehicles without any restrictions, in other countries this is only possible with an appropriate permit or, as in the case of Germany and Belgium, only in certain Länders/cities, while in others driving these vehicles is only allowed on expressways and motorways [12].

Taking into account the above analysis, it would be appropriate to explain what European Modular Systems are, on what basis they are operated and what their characteristics are.

European Modular Systems (EMS) or road trains can be found under various names: Eurocombi, Longer and Heavier Vehicles, Gigaliner, Megatruck, Monstertruck, etc., one can also encounter the term: mega truck or heavy road vehicle $[13,14,15]$.

The above-mentioned vehicles are allowed to move within the European Union in accordance with the Directive $96 / 53$ of 1996 . The document is a legal act regulating the maximum permissible parameters of vehicles. The normative values specified in the directive concern $[12,13]$ :

a. maximum allowable vehicle lengths:

- engine vehicle or semi-trailer - $12 \mathrm{~m}$,

- articulated vehicle - $16,5 \mathrm{~m}$,

- road train - $18,75 \mathrm{~m}$.

b. maximum allowable vehicle widths:

- $2,55 \mathrm{~m}$ - all vehicles,

- $2,6 \mathrm{~m}$ in the case of freezer trucks.

c. maximum allowable height of $4 \mathrm{~m}$.

d. maximum allowable vehicle weight:

- road trains or articulated vehicles - 40 t.,

- articulated vehicles transporting 40 feet long containers - 44 tons. 
In accordance with the Directive 96/53 of 1996, each State within its territory may authorize the movement of vehicles which have different maximum allowable characteristics than the ones determined in the Directive, while respecting the principles of competition in the transport sector. According to the above-mentioned Directive, it is also permitted to use vehicles, trailers or semi-trailers that correspond to the dimensions determined in the act in such combinations that they can achieve at least the loading lengths permitted in that Member State in order to create equal competition conditions for all operators (modular concept) $[12,13]$.

The European Modular System uses transport vehicles that are currently in use in Europe. The configured vehicle sets are $25.25 \mathrm{~m}$ long and can be formed and deformed in any way to create both normative and non-normative vehicles.

They consist of normative and non-normative modules [12,16]:

a. a truck tractor or truck (normative),

b. $13.7 \mathrm{~m}$ long articulated trailer (normative),

c. $7.82 \mathrm{~m}$ long trailer (normative),

d. 2-axle truck (called bogie) (non-normative),

e. special $7.82 \mathrm{~m}$ long 3-axle articulated trailer with a removable container/body at the front equipped with a fifth wheel for attaching another articulated trailer (non-normative).

Using the normative and non-normative modules listed above, allows for the configuration of five possible truck sets $[12,15,16]$.

Modular system configurations are illustrated in figure 1:

a. combination A - 2/3-axle truck tractor hooked with a 3-axle articulated trailer $13.6 \mathrm{~m}$ long, hooked with 8 central trailer of the length up to $7.82 \mathrm{~m}$,

b. combination B - 2/3-axle road tractor connected with a special articulated trailer to be hooked on a standard articulated trailer of the length of $13.6 \mathrm{~m}$,

c. combination $\mathrm{C}-4$-axle $8 \times 2 / 8 \times 4$ chassis hooked on a 3 -axial trailer

d.combination D - 3-axle chassis $6 \times 2 / 6 \times 4$ hooked by a fork lift truck and 3 -axial articulated trailer of the length of $13,6 \mathrm{~m}$

e.combination E - 2-axle chassis hooked with two tandem trailers with $7.82 \mathrm{~m}$ long central axle.

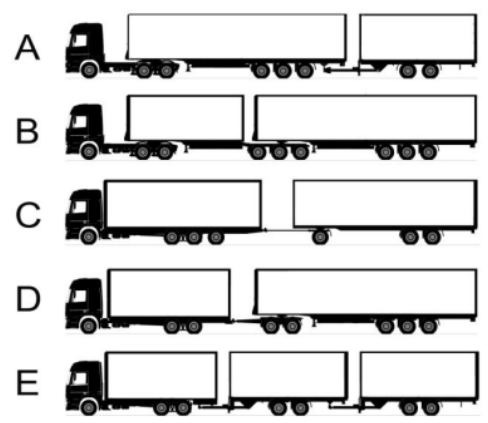

Fig. 1. Modular systems combinations [16].

European Modular Systems used in Europe and worldwide have recently become very popular and this seems to be justified by the ever increasing volume of goods being transported. As the demand for road transport services continues to grow and longer distances are being covered, many countries are allowing for derogations from the Directive admitting longer vehicles for use in their territory.

\section{The comparative analysis of selected cargo means in the Three Seas area route made with the use of Bellinger's method}


Taking into account the above considerations regarding the international economic and political initiative of the Three Seas, which aims at the cooperation of the countries located in the region of the Three Seas, as well as the increasing the use of road trains in Europe, the purpose of the comparative analysis of the selected transport means is to indicate the legitimacy of the use of European Modular Systems (EMS) on the routes located in the Three Seas region.

From the point of view of this study, the relevance of the implementation of the research was found, taking into account the efficiency and economy of the use of the selected cargo means. For the purpose of this paper, a route of $1699 \mathrm{~km}$ from the Port of Stockholm in Sweden to the Port of Rijeka in Croatia was selected. The route is located between the ports of the Baltic Sea and the Adriatic Sea.

Three different sets of vehicles were adopted for the study, which are illustrated in figures $2,3,4$ :

- $\mathrm{S} 1$ - standard set - $16.5 \mathrm{~m}$ long,

- $\mathrm{S} 2$ - set consisting of a motor vehicle and a trailer - $18.75 \mathrm{~m}$ long,

- S3 - EMS - 25,25 m long.
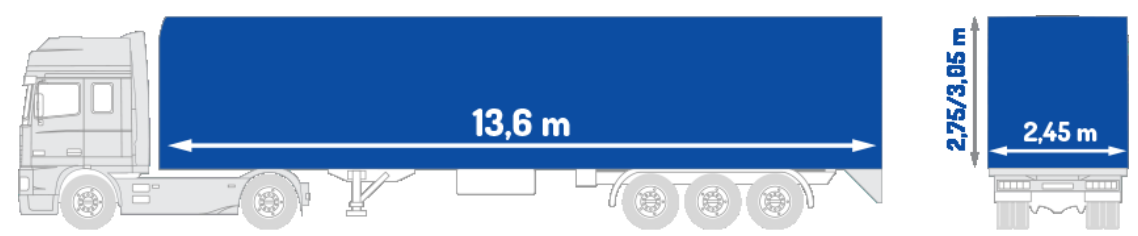

Fig. 2. Standard set - 16,5 m long [19].
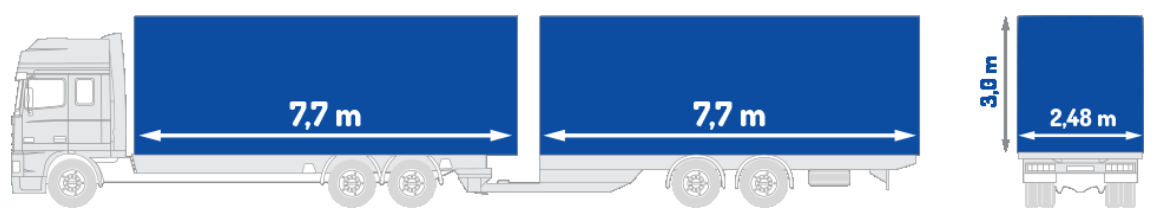

Fig. 3. A set consisting of a motor vehicle and a trailer - $18.75 \mathrm{~m}$ long [19].

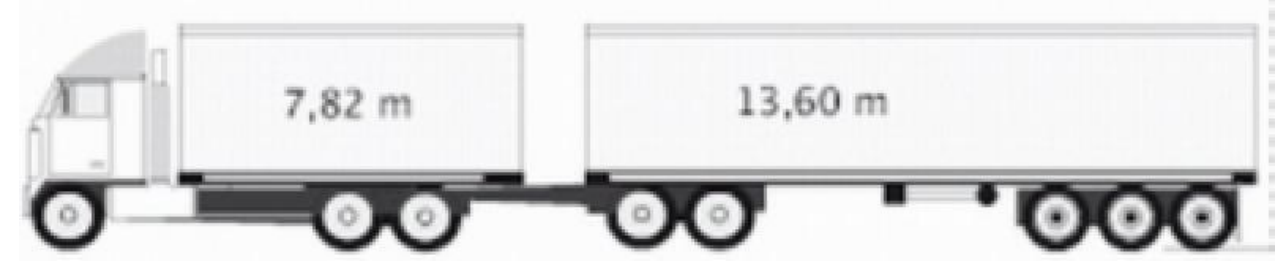

Fig. 4. EMS - 25,25 m long [20].

Based on the data obtained from a transport company, the cost of transporting 1 pallet on this route was calculated for each of the above sets of vehicles. The following data was used for the calculations:

- S1 - total cost - EUR 1,900, loading capacity 34 pallets,

- S2 - total cost - EUR 2,100 loading capacity 38 pallets,

- S3 - total cost - EUR 2,800 Euro, loading capacity 52 pallets.

After making the calculations, the results are as follows:

- S1 - EUR 55.88,

- S2 - EUR 55.26,

- S3 - EUR 53.85.

The calculations will be used to conduct the analysis in a later step. 
In order to make a comparative analysis of the selected cargo means, the Bellinger method was applied. The method allows to order the objects on the basis of the cumulative assessment value, taking into account a set of previously adopted criteria. Due to the fact that the defined criteria are different and come from incomparable sets, assessments of particular values should be brought to comparability and then added up. For each criterion, the most and least desirable state (upper and lower bounds) and the direction of these changes are determined, that is, whether the criterion is a stimulant or a de-stimulant. The detailed procedure in the Bellinger's method is illustrated in figure 5 by the following algorithm $[17,18]$.

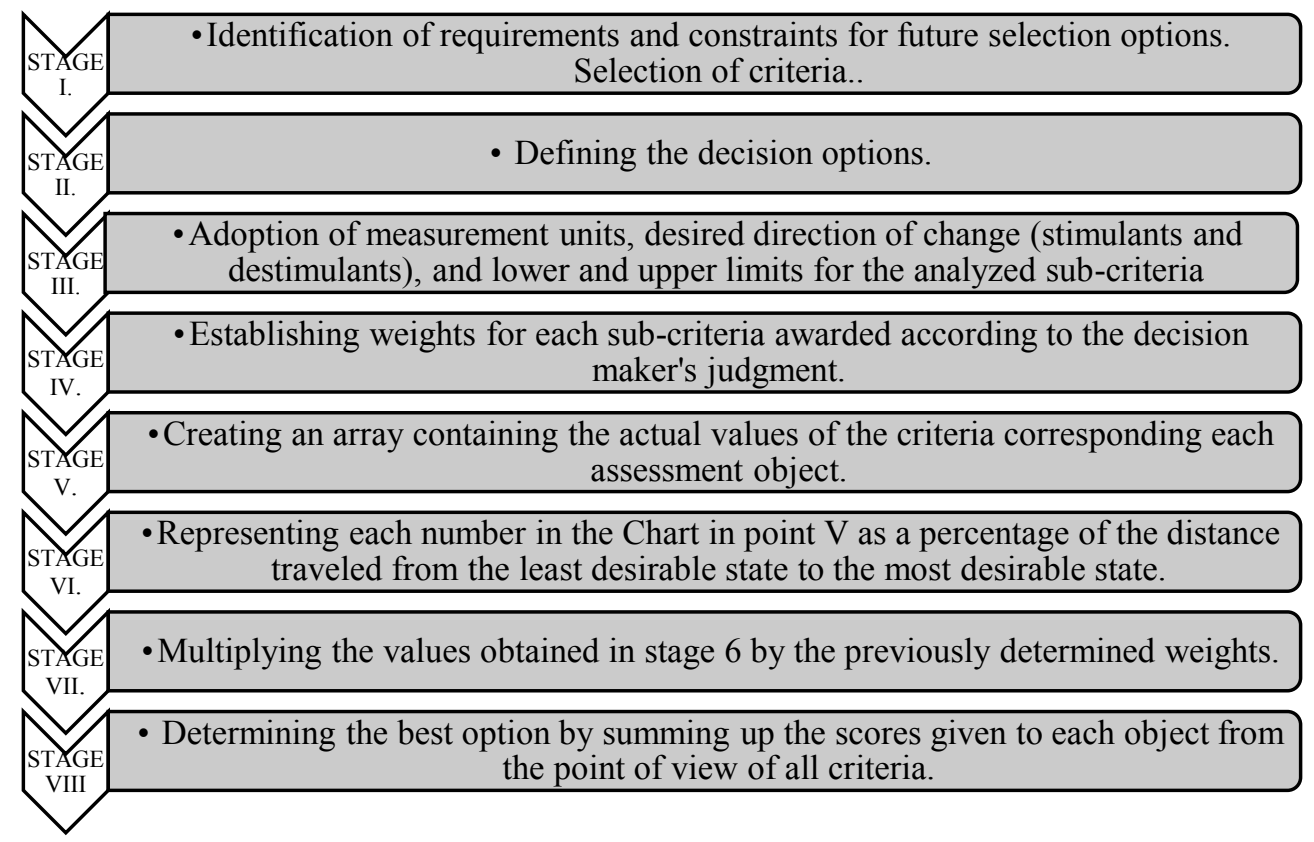

Fig. 5. Algorithm of procedure in the Bellinger method $[17,18]$.

In order to obtain reliable and more accurate results of the analysis, each criterion was assigned an appropriate weight. The weights of each criterion were chosen based on the factors that affect the efficiency and economy of transportation, and thus reduce the cost of transporting a cargo unit. Then, after selecting the five relevant criteria, a questionnaire survey was conducted with 10 decision makers who are responsible for organizing transportation in freight companies. These individuals were asked to assign weights in the form of numerical values for each of the five criteria. It was important that the total of the weight values was equal to 1 .

The following criteria, which, according to the author of this paper, have a bearing on the economy and efficiency of transporting a cargo unit, were examined:

- $\mathrm{C} 1$ - set's length,

- $\mathrm{C} 2$ - number of pallets,

- C3 - loading capacity,

- $\mathrm{C} 4$ - fuel consumption,

- C5 - the cost of transporting one pallet.

The results obtained are summarized in table 1 . The weights for the criteria were labelled consecutively $<\mathrm{C} 1, \mathrm{C} 2, \ldots, \mathrm{C} 5>$. Respondents, on the other hand, were labelled $<\mathrm{R} 1, \mathrm{R} 2, \ldots, \mathrm{R} 10>$. 
Table 1. Values of the weights being the result of the survey.

\begin{tabular}{|c|c|c|c|c|c|c|c|c|c|c|c|}
\hline & R1 & R2 & R3 & R4 & R5 & R6 & R7 & R8 & R9 & R10 & $\begin{array}{c}\text { The } \\
\text { arithmetic } \\
\text { mean }\end{array}$ \\
\hline $\mathbf{C 1}$ & 0,1 & 0,15 & 0,1 & 0,08 & 0,13 & 0,13 & 0,11 & 0,12 & 0,05 & 0,13 & $\mathbf{0 , 1 1}$ \\
\hline $\mathbf{C 2}$ & 0,13 & 0,12 & 0,15 & 0,17 & 0,15 & 0,17 & 0,1 & 0,21 & 0,17 & 0,19 & $\mathbf{0 , 1 6}$ \\
\hline $\mathbf{C 3}$ & 0,17 & 0,09 & 0,13 & 0,07 & 0,1 & 0,16 & 0,14 & 0,15 & 0,2 & 0,25 & $\mathbf{0 , 1 5}$ \\
\hline C4 & 0,25 & 0,36 & 0,32 & 0,35 & 0,25 & 0,25 & 0,32 & 0,25 & 0,33 & 0,16 & $\mathbf{0 , 2 8}$ \\
\hline C5 & 0,35 & 0,28 & 0,3 & 0,33 & 0,37 & 0,29 & 0,33 & 0,27 & 0,25 & 0,27 & $\mathbf{0 , 3 0}$ \\
\hline TOTAL & $\mathbf{1}$ & $\mathbf{1}$ & $\mathbf{1}$ & $\mathbf{1}$ & $\mathbf{1}$ & $\mathbf{1}$ & $\mathbf{1}$ & $\mathbf{1}$ & $\mathbf{1}$ & $\mathbf{1}$ & $\mathbf{1}$ \\
\hline
\end{tabular}

The arithmetic mean of the weights assigned was rounded to two decimal places and expressed as a decimal fraction. The greatest weight was given to the criterion concerning the cost of transporting one pallet, while the criterion concerning fuel consumption was given the second greatest weight. The third criterion important from the point of view of the respondents was the number of pallets transported and the loading capacity. The criterion with the lowest weight value was the length of the set.

Having estimated the values of the weights for each criterion, the units of measurement are presented in table 2, along with the desired direction of change for each criterion (given that a stimulant is the most desirable direction, while a de-stimulant is the least desirable direction). The chart also indicates the assessment ranges for each criterion and the weights assigned to each criterion.

Table 2. List of measurement units with direction of change and weight values for each criterion.

\begin{tabular}{|c|c|c|c|c|c|}
\hline Criterion & C1 & C2 & C3 & C4 & C5 \\
\hline Weights & 0,11 & 0,16 & 0,15 & 0,28 & 0,3 \\
\hline Desired value (upper limit) & 26 & 60 & 50 & 50 & 56 \\
\hline Undesired value (lower limit) & 1 & 1 & 1 & 1 & 1 \\
\hline Desired direction of changes & stimulant & stimulant & stimulant & de-stimulant & de-stimulant \\
\hline
\end{tabular}

The next stage was determining the assessment values of the criteria for the analysis, as illustrated in table 3 .

Table 3. Assessment values of the criteria for the analysis.

\begin{tabular}{|c|c|c|c|c|c|}
\hline Set/ Criterion & C1 & C2 & C3 & C4 & C5 \\
\hline S1 & 16,5 & 34 & 22 & 31 & 55,88 \\
\hline S2 & 18,75 & 38 & 24 & 33 & 55,26 \\
\hline S3 & 25,25 & 52 & 40 & 40 & 53,85 \\
\hline
\end{tabular}

Table 4 then presents the assessment values of the criteria for the analysis as a percentage of roads travelled, from the least to the most desirable condition.

Table 4. Assessment values of the criteria for the analysis as a percentage of roads travelled from the least to the most desirable condition. 


\begin{tabular}{|c|c|c|c|c|c|}
\hline Set/ Criterion & C1 & C2 & C3 & C4 & C5 \\
\hline S1 & $63,46 \%$ & $56,67 \%$ & $44 \%$ & $38,78 \%$ & $0,22 \%$ \\
\hline S2 & $72,12 \%$ & $63,33 \%$ & $48 \%$ & $34,69 \%$ & $1,35 \%$ \\
\hline S3 & $97,12 \%$ & $86,67 \%$ & $80 \%$ & $20,41 \%$ & $3,91 \%$ \\
\hline
\end{tabular}

In the next stage, the obtained percentages were multiplied by the values of the previously adopted weights and then changed into numerical values rounded to four decimal places, as illustrated in table 5 .

Table 5. The results of the multiplication of assessment values and weights for particular criteria.

\begin{tabular}{|c|c|c|c|c|c|}
\hline Set/ Criterion & C1 & C2 & C3 & C4 & C5 \\
\hline S1 & 0,0698 & 0,0907 & 0,0660 & 0,1086 & 0,0007 \\
\hline S2 & 0,0793 & 0,1013 & 0,0720 & 0,0971 & 0,0040 \\
\hline S3 & 0,1068 & 0,1387 & 0,1200 & 0,0571 & 0,0117 \\
\hline
\end{tabular}

The final result of the analysis was adding up the obtained values for the different cargo means. The results are shown in table 6.

Table 6. Cumulative assessment for the analyzed transport means.

\begin{tabular}{|c|c|}
\hline TRANSPORT MEANS & RESULT \\
\hline STANDARD SET & 0,0671 \\
\hline $\begin{array}{c}\text { SET CONSISTING OF A MOTOR VEHICLE AND } \\
\text { A TRAILER }\end{array}$ & 0,0708 \\
\hline EMS & $\mathbf{0 , 0 8 6 9}$ \\
\hline
\end{tabular}

As it can be seen from the above comparative analysis of the three means of transport in view of the five criteria adopted (set's length, number of pallets, loading capacity, fuel consumption, cost of transporting one pallet) the means of transport with the highest number of points is EMS - the European Modular System.

\section{Conclusions}

The conducted analysis allows us to conclude that it is reasonable to continue work on the implementation of infrastructure projects of the Three Seas Fund and the implementation of EMS modular systems in this region.

The use of EMS road sets in the Three Seas area will contribute to:

- increasing the efficiency of the provided transport services,

- a reduction in the number of kilometers travelled with a concurrent increase of freight,

- savings related to the transport of goods by reducing the cost of transporting a cargo unit,

- increasing the efficiency of road transport in relation to other branches of transport as well as the development of intermodal transport,

- ensuring higher loading capacity of a transport vehicle while reducing the number of kilometers travelled, 
- expansion and improvement of the quality of the road and cargo handling infrastructure on the analyzed transport routes,

- connecting the northern part of Europe (Scandinavia) with countries located in the southern part of Europe and further sea routes of the Adriatic Sea and The Black Sea, thus with technologically adapted and unified transport system.

In addition to the above-mentioned advantages of the introduction of EMS sets into service one can also indicate the improvement of safety and the environmental friendliness of their use. The above advantages have not been cited in this study, because the analysis concerned the criteria of efficiency and economy of their use. However, from the point of view of the authors, they are (as well as many other operational aspects [22-27]) equally important and have been analyzed, while the results of their detailed analyses will be presented in subsequent papers.

In conclusion, it can be said that increasing the loading capacity of a means of transport will bring tangible benefits for the transport and freight companies, the economies of the countries located in the Three Seas region, as well as for their customers, as the recipients of the services, due to the reduction of transporting time and the costs of transporting a cargo unit.

\section{References}

1. https://bbats.pl/poradnik-specjalistyczny/transport-miedzynarodowy-spedycjawarszawa/

2. https://www.gov.pl/web/fundusze-regiony/inicjatywa-trojmorza--przechodzimy-dodzialania?fbclid=IwAR1zpIadrytRoBdsAFqFQxJBTWMPuuIkLWg891ZTKKE5TwDY43zD2MZnJM

3. P. Ukielski, Studia Europejskie-Studies in European Affairs, 2, 45-58 (2018)

4. M. Sienkiewicz, Dyplomacja i bezpieczeństwo, 1(4), 139-151 (2016)

5. Wspólna deklaracja w sprawie Inicjatywy Trójmorza, Dubrownik, 25 VIII 2016, Prezydent RP, www.prezydent.pl

6. https://pitd.org.pl/news/inicjatywa-trojmorza-jako-inicjatywa-rozwojuinfrastrukturalnego/?fbclid=IwAR0jfrZcLuP4bS_q1WFDcL4jcqkELAYR3ffX3XE_G VYma9TwuMfmRlhGNSk

7. https://serwisy.gazetaprawna.pl/transport/artykuly/989211,via-carpatia-polskaslowcaja-litwa.html

8. https://300gospodarka.pl/fundusz-trojmorza/via-carpatia-jak-jedna-z-najwazniejszychdrog-w-europie-juz-niedlugo-zmienipolske?fbclid=IwAR0c_DBJBgR36bCzCVIlvkoX1 tntGILYqqlXB8s3yyznji6AhnWZ $\underline{\text { Ropiy0k }}$

9. https://www.gddkia.gov.pl/pl/a/39590/S61-Via-Baltica-Przygladamy-sie-realizacji-tejwaznej-inwestycji

10. B. Zakrzewski, G. Nowacki, R. Kopczewski, AUTOBUSY, 6, 299-308 (2018)

11. https://superbiz.se.pl/wiadomosci/czym-jest-fundusz-trojmorza-inwestycjeinfrastrukturalne-w-tle-aa-8gKC-v6Js-8Qa4.html

12. A. Dzioba, M. Markiewicz' J. Gutsche, Analysis of modular transport systems functioning in selected European countries, MATEC Web of Conferences 332, 01008 (2021)

13. J. Poliński, Przegląd Komunikacyjny, 5, 19-26 (2014) 
14. A. Dzioba, S. Kilimnik, Ł. Muślewski, M. Markiewicz, Czasopismo naukowotechniczne, Postępy w inżynierii mechanicznej - Wydawnictwo Uczelniane Uniwersytetu Technologiczno-Przyrodniczego w Bydgoszczy, 14(7), 75 (2019)

15. Ł. Muślewski, B. Landowski, M. Woropay, K. Migawa, Journal of KONBiN 44, 97 (2017)

16. Ł. Muślewski, M. Lewalski, M. Woropay, Journal of Kones, 22(4), (2015)

17. A. Borucka, Sz. A. Ryrych, Gospodarka Materiałowa i Logistyka, 12, 63-78 (2019)

18. A. Duchaczek, D. Skorupka, Budownictwo i Architektura, 13(4), 351 (2014)

19. http://www.transport-mts.pl/tabor/

20. http://www.strychalski.eu/warto_wiedziec,biblioteka kierowcy zawodowego,porady praktyka,dopuszczalne wymiary i_masy pojazdow.html

21. Dyrektywa Rady 96/53/WE z dnia 25 lipca 1996 r. ustanawiająca dla niektórych pojazdów drogowych poruszających się na terytorium Wspólnoty maksymalne dopuszczalne wymiary w ruchu krajowym i międzynarodowym oraz maksymalne dopuszczalne obciążenia w ruchu międzynarodowym

22. B. Landowski, M. Baran, Analysis of selected results of engine oil tests, MATEC Web of Conferences 302, 01010 (2019), 18th International Conference Diagnostics of Machines and Vehicles, pp.17(2019), https://doi.org/10.1051/matecconf/201930201010

23. B. Landowski, Ł. Muślewski, Numerical simulation of stochastic process as a model of technical object state changes. Engineering Mechanics 2018 Proceedings, Vol 24 Book Series: Engineering Mechanics, 24nd International Conference, may 14 - 17, 2018, Svratka, Czech Republic, Book of full texts, Institute of Theoretical and Appiled Mechanics of the Czech Academy of Sciences, Prague, pp. 485-488 (2018)

24. B. Landowski, D. Perczyński, Ł. Muślewski, P. Kolber, Economic aspects of a city transport means purchase. Proceedings of 58th International Conference of Machine Design Departments - ICMD 2017, Publisher: Czech University of Life Sciences Prague, Czech Republic, pp. 194-199 (2017)

25. A. Grządziela, J. Musiał, Ł. Muślewski, M. Pająk, Polish Maritime Research, 1(85) Vol. 22, 65-71 (2015)

26. Ł. Muślewski, M. Pająk, A. Grządziela, J. Musiał, Journal of Vibroengineering, Issue 3, Vol. 17, 1309-1316 (2015)

27. M. Łukasiewicz, T. Kalaczynski, J. Musiał, J. Shalapko, Journal of Vibroengineering Volume 16, Issue 6, 3137-3145 (2014) 